\title{
Terápiás megfontolások IgA-nephropathiában a legutolsó vizsgálatok (STOP-IgAN, TESTING, NEFIGAN) eredményei alapján
}

\author{
Nagy Judit dr. - Sági Balázs dr. - Máté Judit dr. \\ Vas Tibor dr. - Kovács Tibor dr. \\ Pécsi Tudományegyetem, Általános Orvostudományi Kar, Klinikai Központ, II. Belgyógyászati Klinika és \\ Nefrológiai Centrum, Pécs
}

Jelen tudományos közleményt a szerzők a Pécsi Tudományegyetem alapitásának 650. évfordulója tiszteletére közlik.

\begin{abstract}
Az IgA-nephropathia immunológiai eredetú krónikus glomerulonephritis, amelyet a klinikai kép és a kimenetel nagy változatossága jellemez. A betegség végstádiumú veseelégtelenségig progrediálhat a betegek $25 \%$-ában. Ezért fontos, hogy a progresszióra hajlamos betegeket korán felismerjük. A legfontosabb progressziós rizikófaktorok a perzisztáló proteinuria, hypertonia, csökkent vesefunkció és bizonyos szövettani elváltozások. A jelenleg ajánlott kezelést a 2012-es KDIGO Clinical Practice Guideline foglalja össze. A meglevő rizikófaktorok alapján minden betegnek speciális vesevédő terápiát javasolnak (elsősorban renin-angiotenzin rendszert blokkolókat). A guideline-ban a szteroid/ immunszuppresszív kezelés javaslata alacsony szintű evidenciákra alapozott. Újabban három vizsgálatot szerveztek a speciális vesevédő kezelésekkel együtt adott szteroid/immunszuppresszív kezelés előnyével és rizikójával kapcsolatban. A STOP-IgAN vizsgálatban a szisztémás szteroid/immunszuppresszív kezelés szignifikánsan csökkentette a proteinuriát, de nem állította meg az IgA-nephropathia progresszióját. A TESTING vizsgálatban a szisztémás szteroidterápia szignifikánsan csökkentette a proteinuriát és a progressziót is. Azonban a vizsgálatot idő előtt le kellett állítani a számos súlyos mellékhatás miatt. A budesonidkezelést a NEFIGAN vizsgálatban a bélnyálkahártya immunrendszerének az IgA-nephropathia patogenezisében felvetett szerepe sugallta. A budesonid elsősorban a distalis vékonybélben és a colonban felszabaduló szteroid, amely csökkentette a proteinurát, miközben a vesefunkció változatlan maradt. A számos mellékhatás miatt esetenként leállított kezelés a budesonid szisztémás hatását is felveti. További vizsgálatok szükségesek arra vonatkozóan, hogy mely betegeket kezeljünk szteroid/immunszuppresszív szerekkel a specifikus vesevédő kezelés után és mellett.
\end{abstract}

Orv Hetil. 2017; 158(49): 1946-1952.

Kulcsszavak: IgA-nephropathia, NEFIGAN vizsgálat, szteroid/immunszuppresszív kezelés, STOP-IgAN vizsgálat, TESTING vizsgálat

Considerations on the treatment of $\operatorname{IgA}$ nephropathy on the basis of the results of the latest studies (STOP-IgAN, TESTING, NEFIGAN)

IgA nephropathy is an immune-mediated chronic glomerulonephritis with a great variability in clinical presentation and outcome. The disease can progress to end-stage renal failure in $25 \%$ of patients. For this reason we should identify patients with potential to progress. Most important risk factors for progression are persistent proteinuria, hypertension, decreased renal function and some histological lesions. The actually suggested treatment is summarized in KDIGO Clinical Practice Guideline from 2012. They suggest to give firstly non-specific supportive treatment (especially renin-angiotensin system blocking agents). Recommendation about steroid/immunosuppression treatment is

Az Orvosi Hetilap alapításának 160. évében a Szerkesztőség felkérésére készített tanulmány. 
based on low level of evidence. Recently three studies were organised concerning benefits and risk of steroid/ immunosuppressive treatment added together with specific supportive treatment. In the STOP-IgAN study, systemic steroid/immunosuppressive treatment significantly decreased proteinuria but did not stop progression. In the TESTING study, systemic steroid treatment significantly decreased proteinuria and progression. However, the study was recently discontinued due to several severe side effects of steroid treatment. Involvement of intestinal mucosal immunity in the pathogenesis of IgA nephropathy suggested the NEFIGAN study with budesonide treatment. Budesonide releases corticosteroid in distal small intestine and colon. Proteinuria was significantly decreased and renal function remained stabile. High number of withdrawals owing to adverse effects is a major concern implying a substantial systemic effect of budesonide. We need further information on the characteristics of patients who most likely benefit from steroid/immunosuppressive treatment given after or together with specific supportive treatment.

Keywords: IgA nephropathy, NEFIGAN study, steroid/immunosuppressive treatment, STOP-IgAN study, TESTING study

Nagy J, Sági B, Máté J, Vas T, Kovács T. [Considerations on the treatment of IgA nephropathy on the basis of the results of the latest studies (STOP-IgAN, TESTING, NEFIGAN)]. Orv Hetil. 2017; 158(49): 1946-1952.

(Beérkezett: 2017. augusztus 31.; elfogadva: 2017. szeptember 28.)

\section{Rövidítések}

ACEI $=$ (angiotensin-converting enzyme inhibitors $)$ angiotenzinkonvertálóenzim-gátló; $\mathrm{ARB}=$ (angiotensin receptor blocker) angiotenzinreceptor-blokkoló; GFR $=$ (glomerular filtration rate) glomeruláris filtrációs ráta; $\operatorname{IgAN}=\operatorname{IgA}$-nephropathia; KDIGO = Kidney Disease: Improving Global Outcomes; NEFIGAN $=$ The Effect of Nefecon in Patients with Primary IgA Nephropathy at Risk of Developing End-stage Renal Disease $;$ RAS $=($ renin-angiotensin system $)$ renin-angiotenzin rendszer; UPCR = (urinary protein/creatinine ratio) vizelet fehérje/kreatinin arány; TESTING = Therapeutic Evaluation of STeroids in IgA Nephropathy Global

Az IgA-nephropathia (IgAN) a leggyakoribb primer glomerulonephritis-forma világszerte, amelyet kóros IgAlmolekulákat tartalmazó immunkomplexek glomeruláris, elsősorban mesangialis lerakódása jellemez. (A részleteket lásd késóbb!) Diagnózisa csak a vesebiopszia szövettani vizsgálata alapján lehetséges. Több mint 30 évvel ezelőtt történt felismerése óta kiderült, hogy a kezdetben jó prognózisúnak gondolt megbetegedés sokféle lefolyású lehet; a betegek mintegy $25 \%$-ában lassú progresszió után végstádiumú veseelégtelenség alakulhat ki. Ezért ma már egyértelmú, hogy a betegség mielőbbi felismerése, a progresszióra hajlamos esetek kiválasztása és gondos kezelése, követése elengedhetetlen fontosságú [1-3].

Jelen közleményben röviden ismertetjük az IgAN előfordulási sajátosságait, patogenezisének a legújabb adatait, patológiai diagnózisát és a leggyakoribb klinikai előfordulási formákat. Részletezzük azt a három, közelmúltban publikált terápiás vizsgálatot (STOP-IgAN, TESTING és NEFIGAN), amelyek az általános vesevédő kezelés szteroidterápiával történő kiegészítésének lehetséges jótékony hatását vizsgálták. Végül összefoglaljuk a három vizsgálat alapján az IgAN jelenleg javasol- ható terápiáját, elsôsorban az általános optimalizált vesevédő kezelések fontosságát és a szisztémás vagy lokális szteroidterápia lehetséges helyét a betegek kezelésében.

\section{Előfordulás}

Az IgAN előfordulása az egyes etnikai csoportok és országok között különböző. Leggyakoribb a kelet-ázsiai országokban, Európán belül a déli országokban [4-6]. A klinikailag tünetmentes esetek nagy számával is magyarázható, hogy gyakori azokban az országokban, amelyekben rendszeres vizeletszürő vizsgálatok történnek és a szűrővizsgálattal feltűnt, klinikailag tünetmentes betegekben az etiológia kiderítésére rövid idôn belül vesebiopsziás szövettani vizsgálatot is végeznek [7-9]. Mindezek alapján valószínú, hogy a korán diagnosztizált esetek csak a jéghegy csúcsát jelentik az IgAN-betegek előfordulásában [10].

\section{Patogenezis}

A legújabb eredmények alapján ma az IgAN-t az autoimmun betegségek közé soroljuk [11-14]. Kialakulásához legalább négy lépés szükséges, amelyek a következők:

l. A keringésben kóros szerkezetû $\operatorname{IgAl}$-molekulák jelennek meg, amelyekre az IgAl kapocsrégiójában a galaktózmolekulák csökkenése, úgynevezett galaktózdeficiens IgAl-molekulák kialakulása jellemző.

2. A kóros szerkezetû́ IgAl autoantigénként viselkedik, ellene autoantitestek (elsősorban IgG, ritkábban IgA típusú) keletkeznek.

3. Az autoantigének és az autoantitestek összekapcsolódása immunkomplexeket képez. A keringésben levő IgA-tartalmú immunkomplexek eltávolítása normális körülmények között a májban történik. A kóros IgAlet tartalmazó immunkomplexek azonban nem tudnak 
a májban levő Kupfer-sejtek receptoraihoz kötődve eliminálódni. Ezért a keringésben maradó IgAl-immunkomplexek nagyobb mennyiségben jutnak el a vesékbe és lerakódnak a glomerulusokban, elsősorban a mesangiumban. A lerakódás általában az összes glomerulust érinti, azaz diffúz jellegú.

4. A mesangiumban lerakódott IgAl-immunkomplexek lokális gyulladásos immunreakciót váltanak ki, sejtproliferációval, amelynek során gyulladásos mediátorok szabadulnak fel következményes komplementaktivációval, ami kóros nagyságrendű proteinuria kialakulásához vezethet. Végül az esetek egy részében a glomerulusokban krónikus szklerotikus, irreverzibilis károsodás alakulhat ki, ami a vesefunkció csökkenésével járhat.

\section{Diagnózis}

\section{Szövettani elváltozások}

A betegség diagnózisa kizárólag a vesebiopsziák szövettani vizsgálata alapján lehetséges $[15,16]$. A jellegzetes granulált típusú (immunkomplexek jelenlétét valószínúsítő) glomeruláris, elsősorban mesangialis IgA-lerakódás immunhisztológiai vizsgálattal mutatható ki. Az IgA mellett ritkábban IgG és komplement (C3) jelenléte is kimutatható. Az IgAN legújabb patológiai klasszifikációja, az úgynevezett Oxford klasszifikáció a vesebetegség kimenetelére utaló morfológiai elváltozások súlyosságát pontozza $[17,18]$. Az ez évben közölt, módosított verziója pedig már a félholdas glomeruláris elváltozásokat is figyelembe veszi $[19,20]$.

\section{Klinikai megjelenési formák}

A betegség felismerésekor a klinikai kép számos variációt mutat $[1,2]$ :

A) A leggyakoribb formák:

- leggyakoribb (30-50\%) a tünetszegény proteinuria és/vagy haematuria dysmorph vörösvérsejtekkel;

- gyermekekben és fiatal felnöttekben gyakori (30-40\%) a macrohaematuria (látható vérvizelés), amely elsôsorban felső légúti vagy ritkábban egyéb infekciókkal egy időben jelenik meg és felveti azt a lehetőséget, hogy a nyálkahártya-immunitás kóros múködése szerepet játszhat a kórkép kialakulásában.

B) Atípusos, ritka formák:

- nephrosisszindróma (1,8-6,0\%), amelyben minimális glomeruláris elváltozások (minimal change a glomeruláris állábak összetapadásával) mutathatók ki szövettanilag [21];

- akut veseelégtelenség (3-5\%) makroszkópos haematuriával, amelyben a veseelégtelenség elsősorban a glomerulusokon nagyszámban átmenő, a tubulusokba jutó, a tubulusok lumenében kicsapódó és a vizeletelfolyást akadályozó, ott cilindereket képző vörösvérsejteknek tulajdonítható;
- félholdas forma (2-5\%), a glomerulusok > 50\%-ában friss sejtes, illetve régebbi fibroticus félholdak megjelenésével, amelyek klinikailag gyors progressziójú glomerulonephritis, hypertonia, macrohaematuria képével járhatnak.

Végül megemlítjük, hogy a betegség felismerésekor változó gyakorisággal (5-20\%) látható krónikus veseelégtelenség képe a vesefunkció beszúküulésével, kisfokú vizeleteltérésekkel, hypertoniával. Erre a klinikai képre elsősorban a későn felismerésre kerülő esetekben kell számítani [1, 10].

\section{Prognózis}

A betegség kimenetele egyénenként változhat. A betegek mintegy $25 \%$-a 20 éven belül végstádiumú veseelégtelenné válik, további 25-30\%-ban pedig lassan, de progresszíven csökken a vesefunkció $[10,22,23]$.

A betegség progressziós kockázatának a megítélésében és a terápia megválasztásában a legfontosabb klinikai markereknek a perzisztáló proteinuria, a betegség diagnózisakor mért vesefunkció (glomeruláris filtrációs ráta - GFR) és a hypertonia fennállása bizonyultak [ 1 , 24, 25]. A terápia hatásának mérlegelése szempontjából azonban fontos megemlíteni, hogy a proteinuriát különböző patofiziológiai folyamatok okozhatják: a glomeruláris autoimmun folyamat, amely szteroiddal befolyásolható és glomeruláris hiperfiltráció, amely viszont renin-angiotenzin rendszert (RAS) gátló szerekkel kezelhető.

A prognózist befolyásoló szövettani eltérések az eredeti Oxford klasszifikáció alapján:

- mesangialis hypercellularitas,

- szegmentális glomerulosclerosis,

- endocapillaris hypercellularitas,

- tubularis atrophia és interstitialis fibrosis.

Ötödikként legújabban a glomeruláris félholdak megléte került a felsorolásba $[19,20]$.

A progresszió valószínűsége szempontjából a klinikai kép alapján Floege és Feehally a betegek három csoportba sorolását javasolják [26]:

1. Kis rizikójú betegek: vesefunkció normális, legfeljebb minimális vizeleteltérések vannak (proteinuria $<0,5 \mathrm{~g} / 24$ óra, microhaematuria), hypertonia nincs.

2. Közepes rizikójú betegek: proteinuria >0,5-1,0 g/24 óra, amelyet csökkent vesefunkció és hypertonia kísérhet.

3. Nagy rizikójú betegek: gyors vesefunkció-csökkenés, amely gyors progressziójú glomerulonephritis klinikai képével társulhat.

\section{Terápia}

A betegség oki terápiája jelenleg még mindig nem ismert, bár a patogenezis számos elemére derült már fény $[1,5]$. 
Az általános, nem specifikus (nem etiológiai alapon adott) vesevédő kezelések elsőrendű jelentősége egyértelmü minden beteg esetében. Az általános vesevédő kezelések tervezését és a gyógyszeres és nem gyógyszeres vesevédő kezelések részleteit egy, a közelmúltban megjelent közleményünkben tárgyaltuk, ezért itt nem részletezzük [27].

\section{Szteroid/immunszuppresszin kezelések}

A betegség immunpatogenezise miatt az elmúlt években számos szerző javasolta a betegség szteroid/immunszuppresszív kezelését abból a célból, hogy az IgA elleni autoantitestek keletkezését, az IgA-immunkomplexeknek a mesangialis lerakódását és a kialakuló glomeruláris gyulladásos reakciót megakadályozzák. Ezeket a vizsgálatokat azonban számos kritika érte, fóleg azért, mert a szteroid/immunszuppresszív kezelés megkezdése előtt, illetve a szteroid/immunszuppresszív kezelés alatt nem alkalmaztak következetesen általános vesevédő kezelést, illetve nem megfelelő kontrollcsoportot használtak [28, 29].

A jelenleg ajánlott szteroid/immunszuppresszív kezelést a KDIGO Clinical Practice Guidelines foglalja össze, javaslatai azonban alacsony szintû evidenciákra alapozottak [30].

A közelmúltban három terápiás vizsgálat is befejeződött (STOP-IgAN, TESTING, NEFIGAN), amelyek az optimalizált általános vesevédő kezelések következetes alkalmazásával, illetve azoknak egy második lépcsőben szteroid/immunszuppresszív kezeléssel történő kiegészítésével kapcsolatban készültek, és amelyek tervezésénél igyekeztek kiküszöbölni az előző vizsgálatok hiányosságait. A továbbiakban röviden ismertetjük ezeknek a vizsgálatoknak a terápiás jellegzetességeit, eredményeit, hiányosságait, majd utána összefoglaljuk ezeknek a vizsgálatoknak az IgA-nephropathia terápiájára gyakorolt hatását. A három vizsgálat jellemzőit - betegszám, időtartam, terápia hatására létrejött klinikai javulás, mellékhatások - az 1. táblázatban összegeztük.

\section{STOP-IgAN vizsgálat}

A Németországban készült, a közelmúltban befejezett és publikált STOP-IgAN vizsgálat [31] arra a hipotézisre keresett választ, hogy ha elsőként az optimalizált, huzamosabb ideig alkalmazott általános vesevédő kezelést egy második lépcsőben szisztémás szteroid/immunszuppresszív kezeléssel kombinálunk, az eredményesebb-e a progresszió csökkentésében, mint a hosszú távú optimalizált vesevédő kezelés önmagában. A Floege és mtsai által szervezett multicentrikus, randomizált, kontrollált vizsgálatba $\mathrm{CKD}$ első, második, harmadik stádiumú (eGFR 30-90 ml/min) IgAN-betegeket vontak be, akik proteinuriásak (proteinuria $0,75-3,5 \mathrm{~g} / 24$ óra) és hypertoniásak (vérnyomás $\geq 140 / 90 \mathrm{Hgmm}$ ) voltak, azaz progresszióra hajlamosak.

Az első hat hónapos bevezető periódusban (run-inphase) a betegek csak optimalizált intenzív vesevédő kezelést (amit hely hiányában nem részletezünk) kaptak. A vizsgálatot 309 beteg fejezte be, közülük 94 betegben ( $34 \%)$ a proteinuria $<0,75 \mathrm{~g} / 24$ órára csökkent a periódus végére (reszponderek). Tehát a betegek több mint egyharmadában ez a hat hónapos intenzív vesevédő kezelés a proteinuriát a kívánatos érték alá csökkentette!

A hároméves kezelési periódusba (trial-phase) az a 162 beteg került, akikben a proteinuria a vesevédő kezelésekre nem csökkent a kívánatos érték alá (nonreszponderek). A betegeket randomizáltan két csoportra osztották:

- első csoport (80 beteg): továbbra is csak optimalizált intenzív vesevédő kezelést kapott,

- második csoport ( 82 beteg): a vesevédő kezelés mellé szteroid/immunszuppresszív kezelést kapott a vesefunkció alapján kétféle módon. Ha a GFR >60 ml/ $\min / 1,73 \mathrm{~m}^{2}$ : glükokortikoid-monoterápiát Pozzi és mtsai sémája szerint [32], ha a GFR 30-60 ml/ $\min / 1,73 \mathrm{~m}^{2}$ : prednisolont, cyclophosphamidot, majd azathioprint Ballardie és mtsai kezelési ajánlása alapján [33].

1. táblázat |A legújabb (kettősen vak, placebokontrollált, randomizált) vizsgálatok IgA-nephropathiás, perzisztálóan proteinuriás, optimalizált RAS-gátló kezelést kapó betegek szteroid/immunszuppresszív terápiájával kapcsolatban

\begin{tabular}{|c|c|c|c|c|}
\hline Vizsgálat neve & $\begin{array}{l}\text { Vizsgált betegek } \\
\text { száma }\end{array}$ & $\begin{array}{l}\text { Terápia jellemzői } \\
\text { és időtartama }\end{array}$ & $\begin{array}{l}\text { A szteroid/immunszuppresszív } \\
\text { terápia hatásai }\end{array}$ & $\begin{array}{l}\text { A szteroid/immunszuppresszív terápia } \\
\text { mellékhatásai }\end{array}$ \\
\hline STOP-IgAN & 162 & $\begin{array}{l}\text { Nagy dózisú per os szteroid } \\
\pm \text { immunszuppresszió } \\
36 \text { hónap }\end{array}$ & $\begin{array}{l}\text { Proteinuria csökkent, a progresszió } \\
\text { üteme nem csökkent }\end{array}$ & $\begin{array}{l}\text { Infekciók (egy exit szepszis miatt), } \\
\text { súlynövekedés > } 5 \text { kg és több újkeletü } \\
\text { diabetes már a kezelés első évében }\end{array}$ \\
\hline TESTING & 262 & $\begin{array}{l}\text { Nagy dózisú per os szteroid } \\
36 \text { hónap }\end{array}$ & $\begin{array}{l}\text { Proteinuria csökkent, a progresszió } \\
\text { üteme csökkent }\end{array}$ & $\begin{array}{l}\text { Számos, súlyos mellékhatás, } \\
2 \text { beteg infekció (szepszis) miatt } \\
\text { exitált, ezért a szteroidkezelést idő } \\
\text { előtt leállították }\end{array}$ \\
\hline NEFIGAN & 149 & $\begin{array}{l}\text { Per os TRF-budesonid } \\
9 \text { hónap }\end{array}$ & $\begin{array}{l}\text { Proteinuria csökkent, a progresszió } \\
\text { üteme csökkent }\end{array}$ & $\begin{array}{l}\text { Ritkán szisztémás szteroid kezelésre } \\
\text { jellemző mellékhatások, például } \\
2 \text { mélyvénás thrombosis }\end{array}$ \\
\hline
\end{tabular}

TRF $=($ targeted-release formulation) célzott hatású (szteroid) készítmény 
A vizsgálat végére az első csoport (csak vesevédő kezelések) betegeinek 5\%-a és a második csoport (vesevédő plusz szteroid/immunszuppresszív kezelések) 17\%-a ért el teljes klinikai remissziót (fehérje/kreatinin arány $<0,2$ és stabil vesefunkció, azaz a GFR csökkenése $<5 \mathrm{ml} /$ $\min / 1,73 \mathrm{~m}^{2}$ a hároméves vizsgálat végén). A GFRcsökkenés ütemében és a jelentősebb progressziót mutató betegek számában nem volt a két csoport között szignifikáns különbség. Az első csoport betegeinek 28\%-ában, a második csoport betegeinek 26\%-ában csökkent a GFR $>15 \mathrm{ml} / \mathrm{min} / 1,73 \mathrm{~m}^{2}$-t a hároméves periódus alatt.

A vizsgálat alapján tehát a betegek egy részénél jó hatású volt a szteroid/immunszuppresszió, mert ezek a betegek nagyobb számban értek el teljes klinikai remiszsziót, de ez a jó hatás nem látszott a vesefunkció-csökkenés ütemén. Ugyanakkor a második csoportban több volt a mellékhatás (súlyos és nem súlyos infekciók, diabetes mellitus, csökkent glükóztolerancia, súlynövekedés megjelenése). Egy beteg a második csoportban szepszisben elhunyt.

Összefoglalva: A szteroid/immunszuppresszív kezelésnek a proteinuriacsökkentő hatása egyértelmü, azonban a progressziót csökkentő hosszú távú előnyös hatása egyelőre kérdéses.

\section{TESTING (Therapeutic Evaluation of STeroids in IgA Nephropathy Global) study}

A TESTING study [34] egy randomizált, kontrollált vizsgálat Kínából, amelybe 262 IgAN-beteget vontak be, akik proteinuriásak voltak ( $>1 \mathrm{~g} /$ nap) és az eGFR-jük $20-120 \mathrm{ml} /$ perc $/ 1,73 \mathrm{~m}^{2}$ között változott. A betegek először legalább három hónapig vesevédő kezelést kaptak, beleértve a vérnyomáskontrollt részben RAS-blokkoló szerekkel. A randomizált betegek egyik csoportja $0,6-0,8 \mathrm{mg} / \mathrm{kg} /$ nap metilprednisolont kapott per os, maximum $48 \mathrm{mg}$-ot/nap, amelyet hat-nyolc hónap alatt lassan lecsökkentettek. A betegek másik fele csak vesevédő kezelést kapott. Az időarányos proteinuria a szteroiddal kezelt csoportban szignifikánsan csökkent $(\mathrm{p}<0,001)$. A primer végpontként szereplő renalis kimenetel nyolc, metilprednisolonnal kezelt betegben $(5,9 \%)$ és a placebocsoportból 20 betegben (15,9\%) fordult elő. Azonban a vizsgálatot másfél év után leállították a súlyos mellékhatások miatt, amelyek fóleg infekciókból álltak, két beteg szepszisben meghalt. A részletes vizsgálati eredmények közleményben egyelőre nem jelentek meg, csak a vizsgálati protokoll részletei.

Összefoglalva: A szteroidterápia a proteinuriát szignifikánsan csökkentette és mérsékelte a vesefunkció-csökkenés ütemét is, azonban kérdéses, hogy ez a nagy dózisú szteroidterápia szükséges-e ezen jó hatások eléréséhez vagy kisebb dózis is elegendő lenne-e. A vizsgálat azonban majd csak a részletes eredmények ismeretében lesz értékelhető.

\section{NEFIGAN study}

A NEFIGAN study [35] kettősen vak, placebokontrollált, randomizált vizsgálat, amely 10 európai ország 65 nefrológiai centrumának IgAN-betegei bevonásával készült. A vizsgálat végén 149 beteg adatait értékelték.

A vizsgálatban a betegek budesonidot, egy szintetikus kortikoszteroidot kaptak, amelynek a vizsgálatban használt speciális, célzottan ható formája per os adva gyulladásgátló hatást fejt ki lokálisan a vékonybél distalis és a vastagbél proximalis szakaszán. A speciálisan ható szteroidkészítmény adása azon meggondolásból történt, hogy a bélnyálkahártya és a bél asszociálta lymphoid szövet patogenetikai szerepet játszhat az IgAN kialakulásában [36]. Feltételezhető, hogy IgAN-ban a Peyer-plakkokban levő mucosalis B-lymphocytákban galaktózhiányos IgAl keletkezik [37].

A betegek a hat hónapos bevezetô periódusban (runin-phase) optimalizált RAS-gátló kezelést kaptak.

Az ezt követő kilenc hónapos kezelési periódusba azok a betegek kerültek, akiknek a vizeletében a fehérje/kreatinin arány (UPCR) $\geq 0,5 \mathrm{~g} / \mathrm{g}$ maradt. A bekerült betegek vesefunkciója, a becsült GFR $\geq 45 \mathrm{ml} / \mathrm{min} / 1,73 \mathrm{~m}^{2}$ volt. A betegeket három csoportra osztották, optimalizált RAS-gátló kezelés mellett a betegek az első és második csoportban budesonidot (16 mg/nap, illetve $8 \mathrm{mg}$ / nap), a harmadik csoportban placebót kaptak.

A kilenc hónapos kezelés után a budesoniddal kezelt két csoportban az átlag UPCR 24,4\%-kal (az első csoportban $27,3 \%$-kal, a második csoportban $21,5 \%$-kal) csökkent. A placebót kapott betegekben az átlag-UPCR 2,7\%-kal nőtt.

A kilenc hónapos kezelés után a GFR stabil maradt a két, budesoniddal kezelt csoportban, de 9,8\%-kal csökkent a placebót kapott csoportban.

Mellékhatások:

- a placebokezelt csoportban 50-ból 4 (8\%) betegben szakadt meg a kezelés vagy a követés, 2 -ben mellékhatások miatt;

- a két aktív terápiás csoportban az összes, 99 betegből $25(25 \%)$ betegnél szakadt meg a kezelés vagy a követés, 16 betegben mellékhatások miatt.

A mellékhatások kis része kapcsolatban lehetett a szteroid hatásával (például mélyvénás thrombosisok). A két mélyvénás thrombosis az első csoportban fordult elő. Haláleset nem következett be; végstádiumú veseelégtelenség sem alakult ki egy betegben sem.

Összefoglalva: A vizsgálatban alkalmazott budesonidkezelés szignifikáns proteinuriacsökkenést okozott, a nagyobb dózis nagyobb proteinuriacsökkenéssel járt. A GFR változatlan szintje a vizsgálat ideje alatt arra utal, hogy a budesonid csökkentheti az IgAN progresszióját. A vékonybélben ható, célzott szteroidkezelés mellékhatása kevesebb volt, mint a szisztémás szteroidkezelésé. A néhány, szteroidkezeléssel feltételezetten kapcsolatban álló mellékhatás (mélyvénás thrombosisok) felveti azt a lehetőséget, hogy a budesonid a célzott lokális hatás 
mellett a bélból felszívódva szisztémásan is hat. Így lehet, hogy a proteinuria csökkenése is részben ennek a szisztémás hatásnak tulajdonítható.

\section{A STOP-IgAN és NEFIGAN vizsgálatok összevetése}

Az IgAN súlyossága nem volt egyforma a két vizsgálatban, a NEFIGAN betegei kevésbé súlyosak voltak. A NEFIGAN vizsgálatban a kiindulási proteinuria 1,2 g/ nap volt, ami 25\%-kal kevesebb, mint a STOP-IgANban. A GFR átlaga a NEFIGAN-ban $78 \mathrm{ml} / \mathrm{min} / 1,73$ $\mathrm{m}^{2}$, ami $27 \%$-kal magasabb, mint a STOP-IgAN-ban. A NEFIGAN vizsgálat placebocsoportjában a vizsgálat végén nagyobb GFR-csökkenést észleltek, mint a STOPIgAN-ban szereplő, szteroiddal nem kezelt betegekben, ami arra utalhat, hogy a vizsgálatok kezdetekor a klinikai kép nem reflektálta a patológiai kép súlyosságát. A patológiai kép azonban nem volt ismert egyik csoportban sem [38].

A kreatininből becsült GFR feltehetőleg nem ad pontos felvilágosítást a vesefunkcióról a szteroiddal kezelt betegekben, mert a szteroidterápia az izomzatban keletkező kreatinin csökkenésével járhat. Kérdés, hogy mindez a szisztémás és a lokálisan ható szteroidkészítmények esetében is igaz-e és milyen mértékben.

A kétféle módon alkalmazott szteroid hatásának öszszehasonlítása is nehéz. Egy előző vizsgálat szerint napi $15 \mathrm{mg}$ per os adott budesonid hozzávetőleg napi $20 \mathrm{mg}$ per os prednisolonnal egyenértékű [39].

A STOP-IgAN vizsgálatban az általános vesevédő kezelések sokkal több szempontot vettek figyelembe, mint a NEFIGAN vizsgálatban.

\section{Következtetések}

Mindkét vizsgálat megerősítette a vesevédő kezelések fontosságát és a szteroidkezelés proteinuriacsökkentő hatását. De a szteroid/immunszuppresszív kezelés kedvező hatása a vesefunkció megőrzésében, fenntartásában, sajnos, nem egyértelmú továbbra sem [40]. A szteroid okozta mellékhatások nagy száma pedig megfontolandóvá teszi, hogy melyik betegnek milyen szteroidkészítményt, milyen adagban és meddig adjunk az általános vesevédő kezelések mellett. A budesonid ígéretes új szernek tűnik az IgAN-betegek kezelésében. További vizsgálatokban kellene tisztázni azt a feltételezést, hogy a budesonid primeren lokálisan a vékonybélben fejti ki hatását, és terápiásan biztonságos. Jóval hosszabbra tervezett vizsgálatok szükségesek annak bizonyítására, hogy a proteinuriacsökkentő, vesefunkciót megóvó hatása hosszú távon is megmarad. Célszerü lenne a KDIGO Clinical Practice Guideline megújítása, amelyben a rendkívüli gyakorlati jelentőségü, általános vesevédő kezelések újabb részleteit ismertetik az IgAN terápiájával kapcsolatban.
Anyagi támogatás: A közlemény megírása anyagi támogatásban nem részesült.

Szerzôi munkamegosztás: N. J.: Az adatok értékelése, interpretálása, a kézirat első változatának elkészítése, majd véglegesítése. S. B., M. J.: Irodalomkutatás, az adatok értékelése. V. T.: Statisztikai adatok ellenőrzése. K. T.: Eredmények értelmezése, a kézirat átnézése, szövegezése. A cikk végleges változatát valamennyi szerző elolvasta és jóváhagyta.

Érdekeltségek: A szerzőknek nincsenek érdekeltségeik.

\section{Irodalom}

[1] Nagy J. IgA nephropathy. In: Nagy J. (ed.) Basic clinical nephrology. [IgA-nephropathia. In: Nagy J. (szerk.) A klinikai nephrológia alapjai.] Medicina Könyvkiadó, Budapest, 2015; pp. 122-126. (Hungarian)

[2] Rodrigues JC, Haas M, Reich HN. IgA nephropathy. Clin J Am Soc Nephrol. 2017; 12: 677-686.

[3] Salvadori M, Rosso G. Update on immunoglobulin a nephropathy. Part II: Clinical diagnostic and therapeutical aspects. World J Nephrol. 2016; 5: 6-19.

[4] Woo KT, Chan CM, Chin YM, et al. Global evolutionary trend of the prevalence of primary glomerulonephritis over the past three decades. Nephron Clin Pract. 2010; 116: c337-c346.

[5] Prakash S, Kanjanabuch T, Austin PC, et al. Continental variations in IgA nephropathy among Asians. Clin Nephrol. 2008; 70: 377-384

[6] Sim JJ, Batech M, Hever A, et al. Distribution of biopsy-proven presumed primary glomerulonephropathies in 2000-2011 among a racially and ethnically diverse US population. Am J Kid Dis. 2016 ; 68 : $533-544$.

[7] McQuarrie EP, Mackinnon B, Young B, et al. Centre variation in incidence, indication and diagnosis of adult native renal biopsy in Scotland. Nephrol Dial Transplant. 2009; 24: 1524-1528.

[8] Waldherr R, Rambausek M, Duncker WD, et al. Frequency of mesangial IgA deposits in a non-selected autopsy series. Nephrol Dial Transplant. 1989; 4: 943-946.

[9] Suzuki K, Honda K, Tanabe K, et al. Incidence of latent mesangial IgA deposition in renal allograft donors in Japan. Kidney Int. 2003; 63: 2286-2294

[10] Wyatt RJ. Are we ready for targeted therapy for IgA nephropathy? Lancet 2017; 389: 2083-2084.

[11] Magistroni R, D'Agati VD, Appel GB, et al. New developments in the genetics, pathogenesis, and therapy of IgA nephropathy. Kidney Int. 2015; 88: 974-989.

[12] Boyd JK, Cheung CK, Molyneux K, et al. An update on the pathogenesis and treatment of IgA nephropathy. Kidney Int. 2012; 81: 833-843.

[13] Mestecky J, Raska M, Julian BA, et al. IgA nephropathy: Molecular mechanisms of the disease. Annu Rev Pathol. 2013, 8: 217-240.

[14] Lai KN. Pathogenesis of IgA nephropathy. Nat Rev Nephrol. 2012; 8: 275-283.

[15] Moresco RN, Speeckaert MM, Delanghe JR. Diagnosis and monitoring of IgA nephropathy: the role of biomarkers as an alternative to renal biopsy. Autoimmun Rev. 2015; 14: 847-853.

[16] Floege J, Amann K. Primary glomerulonephritides. Lancet 2016; 387: 2036-2048

[17] Roberts IS. Pathology of IgA nephropathy. Nat Rev Nephrol. 2014; 10: 445-454.

[18] Working Group of the International IgA Nephropathy Network and the Renal Pathology Society. The Oxford classification of 
IgA nephropathy: rationale, clinicopathological correlations and classification. Kidney Int. 2009; 76: 534-545.

[19] Trimarchi H, Barratt J, Cattran DC, et al. Oxford classification of IgA nephropathy 2016: an update from the IgA Nephropathy Classification Working Group. Kidney Int. 2017; 91: 10141021.

[20] Markowitz G. Glomerular disease: Updated Oxford classification of IgA nephropathy: a new MEST-C score. Nat Rev Nephrol. 2017; 13: 385-386.

[21] Herlitz LC, Bomback AS, Stokes MB, et al. IgA nephropathy with minimal change disease. Clin J Am Soc Nephrol. 2014; 9: 1033-1039.

[22] Gutiérrez E, Zamora I, Ballarín A, et al. Long-term outcomes of IgA nephropathy presenting with minimal or no proteinuria. J Am Soc Nephrol. 2012; 23: 1753-1760

[23] Zhang C, Zeng X, Li Z, et al. Immunoglobulin A nephropathy: current progress and future directions. Transl Res. 2015; 166: 134-144.

[24] Canetta PA, Kiryluk K, Appel GB. Glomerular diseases: emerging tests and therapies for IgA nephropathy. Clin J Am Soc Nephrol. 2014; 9: 617-625.

[25] Maixnerova D, Reily C, Bian Q, et al. Markers for the progression of IgA nephropathy. J Nephrol. 2016; 29: 535-541.

[26] Floege J, Feehally J. Treatment of IgA nephropathy and Henoch-Schönlein nephritis. Nat Rev Nephrol. 2013; 9: 320-327.

[27] Nagy J, Vas T, Kovács T. News in the pathogenesis, diagnosis and treatment of IgA nephropathy. (Újdonságok az IgA-nephropathia patogenezisében, diagnózisában és kezelésében.) Hypertonia és Nephrologia 2016; 20: 253-258. (Hungarian)

[28] Glassock RJ. Moderator's view: Treatment of IgA nephropathy - getting comfortable with uncertainty. Nephrol Dial Transplant. 2016; 31: 1776-1780.

[29] Rasche FM, Keller F, Rasche WG, et al. Why, when and how should immunosuppressive therapy considered in patients with immunoglobulin A nephropathy? Clin Exp Immunol. 2016; 186: 115-133.
[30] KDIGO Clinical Practice Guideline for glomerulonephritis. Chapter 10: Immunoglobulin A nephropathy. Kidney Int Suppl. 2012; 2: 209-217.

[31] Rauen T, Eitner F, Fitzner C, et al., for the STOP-IgAN Investigators. Intensive supportive care plus immunosuppression in $\operatorname{IgA}$ nephropathy. N Eng J Med. 2015; 373: 2225-2236.

[32] Pozzi C, Andrulli S, Del Vecchio I, et al. Corticosteroid effectiveness in IgA nephropathy: long term results of a randomized, controlled trial. J Am Soc Nephrol. 2004; 15: 157-163.

[33] Ballardie FW, Roberts IS. Controlled prospective trial of prednisolone and cyclotoxics in progressive IgA nephropathy. J Am Soc Nephrol. 2002; 13: 142-148.

[34] Lv J, Xu D, Perkovic V, et al., for the TESTING Study Group. Corticosteroid therapy in IgA nephropathy. J Am Soc Nephrol. 2012; 23: 1108-1116.

[35] Fellström BC, Barratt J, Cook H, et al., NEFIGAN Trial Investigators. Targeted-release budesonide versus placebo in patients with IgA nephropathy (NEFIGAN): a double-blind, randomised, placebo-controlled phase $2 \mathrm{~b}$ trial. Lancet 2017; 389: $2117-$ 2127.

[36] Kiryluk K, Li Y, Scolari F, et al. Discovery of new risk loci for IgA nephropathy implicates genes involved in immunity against intestinal pathogens. Nat Genet. 2014; 46: 1187-1196.

[37] Coppo R. The intestine-renal connection in IgA nephropathy. Nephrol Dial Transplant. 2015; 30: 360-366.

[38] Glassock RJ. Glomerular disease: Targeted steroid therapy for IgA nephropathy. Nat Rev Nephrol. 2017; 13: 390-392.

[39] Edsbäcker S, Nilsson M, Larsson P. A cortisol suppression doseresponse comparison of budesonide in controlled ileal release capsules with prednisolone. Aliment Pharmacol Ther. 1999; 13: 219-224.

[40] Coppo R. Biomarkers and targeted new therapies for IgA nephropathy. Pediatr Nephrol. 2017; 32: 725-731.

(Nagy Judit dr., Pécs, Pacsirta u. 1., 7624 e-mail: judit.nagy@aok.pte.hu)

\section{"Intemperantia medicorum nutrix." (Az emberek mértéktelensége az orvosok jótevője.)}

